\title{
Some psycholinguistic conditions for second language learning
} Bernard Spolsky

The author discusses some psycholinguistic conditions for second language learning based on a preference $\mathrm{m}$ odel in linguistics. The outcome of second language learning depends on a number of conditions. Second language learning takes place in a social context, and social conditions determine a learner's attitudes. These attitudes are twofold in nature, namely those towards the community speaking the target language and those towards the learning situation. The two kinds of attitudes lead to motivation. The social context also provides opportunities for language learning and can be divided into formal and informal situations. There are also individual conditions of the learner. The author is concerned with the exploration of several specific psycholinguistic factors, as well as the kinds of rules which they contribute to the theory.

Die skrywer bespreek enkele psigolinguistiese voorwaardes vir die aanleer van 'n tweede taal, gebaseer op ' $n$ voorkeurmodel in die linguistiek. Die aanleer van 'n tweede taal geskied binne 'n sosiale konteks, en sosiale omstandighede bepaal 'n leerder se houding. Hierdie houding kan bestaan ten opsigte van die gemeenskap wat die teikentaal praat, sowel as ten opsigte van die leersituasie. Motivering word bepaal deur hierdie tweeledige houding. Die sosiale konteks bepaal ook geleenthede vir die aanleer van 'n taal en kan verdeel word in formele en informele situasies. Verder is daar die individuele omstandighede van elke leerder. Die skrywer hou hom besig met 'n verkenning van spesifieke psigolinguistiese faktore, sowel as die soort reëls wat bydra tot die teorie.

In this paper; I will discuss some psycholinguistic conditions for second language learning in terms of a theory of second language learning based on a preference model in linguistics (Jackendoff 1983). The general outline of the theory is as follows:

The achievement of the many possible outcomes in second language learning depends on meeting a number of conditions: Some are necessary, as without them learning is impossible; many are graded, in other words there is a relation between the extent to which the conditions are met and the outcome, and others are conditions that apply typically but not necessarily. Second language learning takes place in a social context, which constitutes the first set of conditions. Social conditions determine a learner's attitudes which are divisible, according to Gardner (1979), into those directed towards the community speaking the tar- get language ("integrativeness") and into those directed towards the learning situation. The two kinds of attitudes, according to Gardner, lead to motivation. The social context also provides opportunities for language learning; these may be grouped roughly into formal and informal situations. There are also conditions individual to the learner: The language learner brings with him or her a number of capabilities and a body of previous knowledge and experience. Some of these are universal, such as an innate capability for deriving a grammar, an innate or learned ability to infer interpretation from speech acts, and presuppositions about the uses of language; while these are basic, they do not have a special capacity to explain variation in the outcomes. Others, linguistic or non-linguistic, are specific to the learner's own background. Of particular importance are previous knowledge (of the first or other languages), language learning aptitude and motivation. The com- 
bination of these learner factors accounts for the use the learner makes, consciously or unconsciously, of the socially provided formal or informal learning situations.

My concern in this paper will be to explore several specific psycholinguistic factors, and sketch the kinds of rules which they contribute to the theory.

\section{Human learner}

I start with the absolute and necessary condition for second language learning, a human learner, and propose:

Condition 1 (necessary): This theory of second language learning deals with the learning of a second or later language by a human being who has already learned a first language.

While this may at first glance seem trivial and obvious, it is in fact interpretable as an empirically verifiable claim of some theoretical importance. There are alternatives: One might want to set as a requirement for a theory of second language learning that it account for an animal learning to respond to human signals and to produce signals interpret. able by human beings, or for the possibility of programming a computer to produce or accept a natural language. ${ }^{1}$ Now, both these requirements are interesting, but in the first place they complicate the task. Secondly, the decision to make them requisite must depend on proof that they are generalizably similar to human second language learning. This evidence would only come from knowing more than we do about the physiological processes underlying human language use. For this reason, we will next consider the nature of the central physiological organ underlying language, the brain.

\section{The neurolinguistics of language learning}

In an excellent recent introduction to the psycholinguistics of second language learning, Hatch describes the neurolinguistic basis of language as something still to be established: "Where messages go and what happens to them are two of our most intriguing unanswered questions" (1983:198). Obler (1983) suggests that our "rudimentary" knowledge is a result of limitations of methodolo- gy. The black box remains opaque, but there are a number of more or less informed and more or less plausible guesses about how it might work, and some more or less imaginative guesses about the implications of the first set of guesses for second language learning. Galloway (1981) summarizes research evidence on the neuropsychology of bilingualism and second language performance as follows. Advanced second language learners and bilinguals appear to be equally lateralized in cach of their languages although some studies suggest that language in some bilinguals is more evenly divided between the hemispheres than in monolinguals and there are reported differences (in contradictory directions) according to age of learning. There are hypotheses, but no hard evidence of language-specific differences and ethnic differences. A group of papers at the 1981 TESOL Convention summarized research in the field of neurolinguistics and second language acquisition (Cohen 1982) and supports the conclusion that the body of hard data on the neurolinguistics of second language learning comes nowhere near matching the enormous amount of speculation.

Even though there is no hard evidence of the functioning of specific parts of the brain, a good deal has been inferred from behavioural changes. One critical question to be considered is the effect of brain damage on the ability to learn a second language. From data collected in monitoring the various immersion programmes for teaching French in Quebec, Genesee (1983) concludes that the extra language learning did not impose an educational disadvantage on low-IQ or learningdisabled children. Learning disability as defined in his studies, is not a block to learning a second language and functioning in it.

The difficulty of making hard claims results from the fact that when we are studying a person with some kind of brain damage, our evidence may just as well be that of a reorganized brain as of a brain with one functioning section. This point may be clearer if we consider other kinds of physiological defects and their effects on second language learning. Someone with a broken arm speaking a language that requires the use of frequent large nonverbal gestures clearly suffers from a "speech" impediment, but will usually be able to overcome that difficulty by modification of intonation and stress. A person temporarily prevented from speaking as a result of oral surgery will similarly use 
a combination of gestures and written messages. Someone who is partially deaf develops lip-reading skills. In all these cases, there has clearly been a reorganization of skills and the implementation of ways to replace the missing part. The same is probably true of many cases of brain impairment.

These arguments then militate against imposing necessary neurophysiological conditions on second language learning that are different from those we would impose on normal learning activities. The first necessary condition, ' iz that we are concerned with a "human being" does not need more precise categorization; we assume that "human being" is defined by the normal set of rules, with the normal necessary conditions (alive, conscious of the outside world, in control of some non-reflex responses) and the normal typical conditions (intact body, functioning sense organs). Just as not meeting a typical condition (the loss of a limb or the impairment of a sense organ) does not lead us to consider someone not human, so it does not rule out the possibility of second language learning.

\section{The argument from linguistic theory}

There is an important argument for a biological basis for language learning in current linguistic theory. Chomsky has drawn attention to what he labels "Plato's problem", the fact that children show evidence of knowing things about language that they could not have gained from their outside experience; he therefore proposes that there are certain language properties inherent in the human mind. These form a Universal Grammar, not a set of particular rules but a set of general principles about the possible form of grammatical rules: a metagrammar, to be precise. These universal grammar rules include "parameters" which are specifically applied to the grammars of individual languages, they are present in the brain and develop as the child grows, given certain environmental "triggers" (Chomsky 1980:33).

The Universal Grammar may be present as a whole from the beginning and applied only as needed, or it may itself develop over time. This theory deals with linguistic or grammatical competence or knowledge of a language and not with what Chomsky calls pragmatic competence: The ability to place "language in the institutional setting of its use, relating intentions and purposes to the linguistic means at hand" $(1980: 225)^{2}$. Secondly, Chom- sky (1982) makes clear that the principles of the Universal Grammar are more important than the rules: A grammar is the specification of the way in which parameters are set. Thirdly, there is a distinction between the "core" grammar set by the Universal Grammar and "peripheral" marked constructions that might have other sources (1980:8). In practice then, the child's experience applies parameters according to the basic principles of the Universal Grammar; while it "prefers" to apply these Universal Grammar principles, it may use other processes for a periphery of marked features. There is, however, no reason to assume that the core develops first; unmarked structures may emerge late, frequency may have an effect (Chomsky 1981:9). Hypothesis-testing may be an explanation, but it should be seen as choosing from a limited number of possibilities set by the Universal Grammar.

Applying this theory to second language learning, Cook (1984) proposes that the same argument holds: A second language learner shows evidence of knowing facts that he or she has not been taught. But there is a critical difference: The second language learner already has a grammar that itself has developed by applying the principles of the Universal Grammar available. The question which then arises is whether the learning of a second language can still involve fixing parameters in the Universal Grammar or whether, in accordance with the Critical Period Hypothesis proposed by Lenneberg (1967), the principles and parameters of the Universal Grammar are no longer accessible to the learner after a certain age.

Of the greatest importance for this argument is the postulation of a biologically inherent process, a language acquisition device, if we want to use the metaphor, related in complex ways to general cognition and expressible in terms of a Universal Grammar which consists of a set of principles and a set of parameters which apply to a specific language. It must be considered a necessary condition. If the theory is correct, the Universal Grammar is as much a part of a human being as is any other physiological organ; its absence leads to serious disablement.

Condition 2 (necessary): Any physiological or biological limitations that block the learning of a first language will similarly block the learning of a second language. 
It is important to note that we are not talking about a graded or typical condition: There is no evidence to suggest, nor theories that argue, that some people are equipped with better Universal Grammars than others. ${ }^{3}$

\section{Age}

Earlier I mentioned the claim that all or critical parts of second language learning are dependent on some innate preprogrammed mechanism, identical or similar to the Language Acquisition Device proposed for first language learning. A second claim is that this mechanism is differentially available, in relation to age (the Critical Period Hypothesis) or in relation to the nature of affect or input conditions (Krashen's hypotheses concerning the learning-acquisition distinction, the affective filter, and comprehensible input).

Like other questions in second language learning, the age issue is also a result of the blurring of boundaries: In a model looking only at informal second language learning and bilingualism, we naturally tend to assume that children learn languages better than adults; when we are studying what happens in our own foreign language classroom, we often believe that the best age for learning was the year before the students came to us; and the instrument by which we measure language proficiency usually determines who will have learned best in a comparative study. Educational systems usually first decide the optimal learning age on political or economic grounds and then seek educational justification for their decision. For these reasons, the research evidence on the question is far from clear or conclusive. But the theoretical importance of the issue is considerable. If differences between first and second language learning can be accounted for by age differences (as in the Critical Period Hypothesis), then we clearly have a biological basis for learning (a developmentally related biological innate programme). On the other hand, if Krashen is right about the differential availability of an acquisition processor at all ages, we have a ready explanation for both the comparative failure of most foreign language teaching methods (they deal only with the monitor, and so with low-level minimally useful rules) and for the large numbers of adults who cannot learn second languages, as they are restricted either developmentally or affectively to monitor learning.
If the process is biological, it should show changes with age: Either one should be unable to learn certain things before a certain age (as in Piagetian models) or one should lose the plasticity of childhood as an adult. Indeed, one of the major arguments for a biological basis for all language lcarning is that after puberty second language learning is not as completely successful as before it. Let us look at some of the evidence that can bear on this issue.

In a study of the age of learning, Fathman (1975) looked not just at overall performance but at the order of learning specific structures. She arrived at two interesting conclusions: First, that the age of learning did not seem to make any difference to the sequence of learning these items, and second. that age of learning made a difference in performance on phonology (where younger learners did better) and morphology (where there was an advantage for older learners). Felix (1981) studied young German children learning English in a "liberal audiolingual" classroom, where most of the classroom activity was repetition, drill, and controlled question-answer dialogues. No spontaneous novel utterances were allowed, thus the classroom gave virtually no opportunity for natural speech, nor did these children have any exposure to English outside it. Nevertheless, in four structures studied, he found striking similarities between the utterances of tutored and naturalistic second and first language learners; he was ready to conclude that "at least some of the principles that govern naturalistic language acquisition also determine the processes by which students learn a foreign language under classroom conditions" (Felix 1981:108). Swain (1981) looked at the relative advantages of early and late starts to immersion programmes in Canada. Since Ervin-Tripp (1974) showed some of the ways in which older children learn certain aspects of language more efficiently than younger children, a good deal of evidence has evolved that being young has as little advantage in language learning as in many other aspects of life. Swain found that late immersion learners had many better results than early immersion learners. For school related learning, at least, and in the circumstances of French immersion programmes in Canada (Swain emphasizes the sociological context and the fact that it is the majority child learning a minority language), an earlier start has much less effect than might have been expected. Swain's study does not contradict the general agreement that there are 
certain aspects of second language learning, especially the more school-related tasks (and the areas that Krashen ascribes to the monitor), that older learners have more success with; nor does it contradict the general finding that the earlier one starts to learn a language, the more success one has in developing native-like pronunciation.

There is also evidence, summarized in Dulay, Burt and Krashen (1982) about the effects of starting to learn a second language while young. Studies of a group of Italian-born male immigrants who had been living in the USA for from five to eighteen years showed that the age of arrival had a major influence on the presence or absence of a noticeable accent. Age of arrival was also the main factor in accounting for accent. but when length of stay in the country was less than five years, it became significant. It should be noted that all these studies assume a minimum initial period (say five years) for someone who is young enough (under 9 to be fairly sure of success, under 15 to have a good chance of it) to acquire a native-like accent. And all these studies report the existence of a noticeable minority who are exceptions. This fact surely argues against any absolute biological basis, and leads us to assume a preference rule:

Condition 2 (graded typical): The younger one starts to learn a second language, the better chance one has to develop a native-like pronunciation.

It should be noted that the statement of this rule does not attempt to explain the phenomenon, viz whether it is a question of time, or plasticity of muscular co-ordination, or openness to new language ego. What is important at this stage is to see that we have found no support for a necessary condition even in the area of pronunciation. There is less evidence available on differences in grammar than on differences in phonology. Some grammatical tests seem to favour younger arrivals, but in school learning of testable morphology and syntax, there is evidence that older learners learn faster than younger (Swain 1981, Ervin-Tripp 1974).

Assuming that these age differences have been established, what are the possible explanations? There are essentially four to be considered: the biological, the cognitive developmental, the affective, and the environmental. We have already touched on the biological. Here, I will simply say that there does not seem to be much evidence for the suggestion that there is a critical period, associated with lateralization, and for the implication that language learning atter lateralization is different, and no reason for setting it as a necessary condition.

When we turn to look at a cognitive developmental explanation, we can certainly assume that the kind of formal abstract task called for in much classroom teaching of foreign languages is likely to be more within the competence of the older child or adolescent. Swain in fact argues convincingly that much of the school training given in the native language is likely to be useful to the second language learner in developing related skills (Bialystok 1981).

Condition 3 (graded typical): The formal classroom learning of a second language is promoted by the development of the skills of abstraction and analysis.

The following affective hypothesis is formulated by Schumann (1975). Having reviewed the various studies concerning the importance of attitudes, motivation, and personality in second language learning and having noted the weakness in the neuropsychological arguments for a critical period, he proposes an affective explanation for children's superior success in certain aspects of language learning. Essentially, he follows Macnamara (1973) who argues that children learn better than adults because they try harder to communicate. He goes on to suggest that the reason adults often do not get involved in this "real communication", essential to learning, may be socialization; children are given greater opportunities to interact than are adults, and adults are more able and likely to find ways of avoiding interaction in the new language.

Condition 4 (graded typical): A child's greater openness to external influence favours the learning of a second language in informal situations.

The final argument, that children learn languages in environments different from those of adults, is clearly true. Schumann recognizes the differences in communicative needs that might result from these differing sociological conditions, although he prefers to relate them to the learner's attitudes. 
Condition 5 (graded typical): The social situation faced by a child in a second language environment favours second language learning.

\section{Individual differences}

There is certainly a good deal of evidence that human beings vary considerably in the range of abilities that underlies the construct labelled intelligence. To what extent is intelligence, however defined, a necessary condition, a mark of humanness, and to what extent is it a graded condition relevant to second language learning? The answer to this has in part to do with the relation between general cognitive ability and specific language ability, which may be summed up in two claims:

a There is a language-specific ability or faculty, distinct from other cognitive abilities. The work of modern generative grammarians is based on this claim, and sets out to justify it by showing the existence of language-specific principles such as those we have been discussing under Universal Grammar.

b This language-specific ability must be consistent with other aspects of the cognitive system, because it interacts with and makes use of them. Jackendoff (1983) presents this claim first as the "Cognitive Constraint", viz there must be levels of mental representation at which information conveyed by language is compatible with information from other peripheral systems (1983:16). He suggests that one can in fact go further than to point out the need for interfaces between the various sensory modalities. He proposes in other words a strong form of Piagetian developmental theory, a hypothesis of the existence of a level of conceptual structures that are universal and innate but specifically developed by experience and at which linguistic, sensory, and motor information are compatible (1983:17).

Cook (1985) points out that there is no reason to suppose that the "mental faculty of language" depends, as Piaget would claim, on certain cognitive operations; he, however, misses Jackendoff's point when he says that there is no necessary connection between language and other faculties. But, Cook points out, there are other ways in which the language faculty and the other cognitive faculties are related. Just as language development is tied to physical development in specific ways, such as the influence of the development of the nervous system on phonology, so the use of certain language abilities depends on the availability and development of certain general, cognitive abilities. Cook mentions the example of the constraint of short term memory on sentence length. Jackendoff points out that the richness of semantic structure is dependent on conceptual richness, and so relates language to cognition.

We have here a clue to an important set of distinctions. In the conditions we have been considering so far, there is a basic necessary condition that must be met, a sort of core minimum. At the same time, there is clearly the possibility of stating a graded condition. Take language learning. It is generally accepted now that both innate and environmental conditions must be met: The grammarians have given us reason to believe in the necessity of the innate Universal Grammar, and they fully agree with others that there is need for exposure to the language. ${ }^{4}$ Now it is clear that there is variation in the amount of exposure. Might not there also be variation in the quality of the innate component?

The argument is at first sight an appealing one. If all men are not created equal, we can more easily avoid responsibility for inequality. It is also a socially irresponsible theory that leads to racism and other forms of extreme discrimination against any persons considered innately inferior. There is, therefore, good moral reason for demanding particularly strong proof on biological grounds for differences between human beings.

If we apply this to language learning, we should first stress, therefore, the universality of the language faculty (and so by definition the language learning ability) in non-pathological human beings. As we can find no significant biological differences between first and second language learning (rejecting the Critical Period Hypothesis), we will not expect to find that differences in the fact of second language learning are biologically explainable. We still need to consider the possibility of biological influence on the quality or quantity of second language learning, and while it will be reasonable to hold that many of the differences in individual second language learning achievement will be accounted for by environmental and other factors, we still need to look at two potentially 
biological explanations, intelligence or general cognitive ability, and language aptitude or specific language ability.

\section{Intelligence}

There has been a controversy between Oller and others over Oller's (1981 and elsewhere) claims that general intelligence and language proficiency are more or less the same thing. This argument follows from his claim that a general factor exists in language tests and that it has a high correlation with the results of language tests. The issue is also related to the various attempts of Cummins $(1980$, 1983 and elsewhere) and some of his colleagues to chart the difficult seas of the relations between school-valued abilities and non-school social communicative abilities, an issue tied up with problems of assessing intelligence and comparing social class differences. The explanation for their observations lies in the difficulty of gathering evidence of both language ability and general intelligence. Both make use of various kinds of tests, and there is good reason to suspect that we are then dealing with their shared components. Moreover, both depend (if we accept Jackendoff's hypothesis) on the richness of conceptual structure. At the same time, both are at the mercy of the particular cultural bias of the testing instrument. The most that we can safely say is that there is a high correlation between the scores on intelligence tests and the scores on formal tests of school-related language abilities.

This point is very. well illustrated by a recent study by Genesee (1976) in which he looked at the relevance of intelligence (as measured by standardized IQ tests) to performance in immersion and non-immersion French programmes in Montreal. He found that while intelligence was a predictor of the learning of school-related academic language skills, it did not seem to predict the learning of communication skills, even as shown in schooladministered interview situations. We may state this as a graded condition:

Condition 6 (graded typical): The ability to perform well on standard intelligence tests correlates highly with school-related second language learning (i.e. in functional terms, such tasks as reading and writing of academic material in formal language and as performing abstract tests of structural knowledge) but is unrelated to the learning of a second language for informal and social functions.

\section{Aptitude}

Intelligence was one of the factors considered as a candidate for predicting language aptitude. The question faced by those who tried to develop language aptitude tests was what other measures would predict language learning in a school situation. While the earliest language aptitude tests date from the 1930's (e.g. the Symonds Foreign Language Prognosis Test, 1930), the important work was done by Carroll and Sapon developing the Modern Language Aptitude Test published in 1959 and a decade later, the Elementary Modern Language Aptitude Test (1967) and by Paul Pimsleur with his Language Aptitude Battery (1966). As Stern (1983) points out, these tests are interesting not just for their practical usefulness but for their theoretical claims, the most obvious of which is that language aptitude is not a single factor, but a cluster of specific abilities. By analysing the components of each of the tests, as Stern does (1983:371), it is to be seen that several main components are postulated: auditory ability, grammatical sensitivity, and memory.

It would seem that the aptitude tests are concerned, as of course they should be, with the learning of a language for school-related purposes and in a school situation. The assumption remains that they measure, in a school-related way, aspects of aptitude that are likely to be important in accounting for some of the individual differences in informal learning. Each, in other words, taps a graded component of necessary human abilities: the ability to discriminate the sounds of the new language, the ability to generalize about its structure, and the ability to remember its words. Without some basic minimum, no second language learning is possible. The more each is present, the faster control will be achieved and the higher the potential level of success.

Condition 7 (graded necessary): In learning to speak and understand a second language, the better a learner can discriminate between the sounds of the language, the better his/her knowledge will be.

Condition 8 (graded necessary): In learning a new language, the better the learner's memory, the faster he/she will learn new items and the larger his/her vocabulary will be. This ability may be 
different for learning words aurally or for learning them visually.

Condition 9 (graded necessary): Beyond the necessary miminum ability to "derive a grammar" implicitly, the better a learner's ability to generalize about the structure of the second language (from explicit or implicit generalizations, in whatever forms), the faster he/she will develop control of the grammatical (and pragmatic) structure of a second language.

\section{Attitude and personality}

Attitudes and motivation are more a part of the individual learner than of the society, but they are very greatly influenced by the social context. Here, I shall only deal with personality factors that at the outset might seem to be independent of social context, although they may predict an individual's social behaviour and may be differentially interpreted and valued (and so reinforced?) in various social groups. I will leave the socially influenced factors of attitude and motivation to be considered at another time.

The main studies concerning personality are those of Guiora and the University of Michigan Personality and Language Behavior Research Group. The theoretical framework is restated in Guiora and Acton (1979). The basic question is: "How will language affect personality development and how will personality development in turn affect language behavior?" (1979:195) Guiora's exposition of the importance of personality factors in second language learning is made clearest in two recent papers $(1982,1983)$. He argues there that language is not just a means of communication but a method of self-representation. Learning a second language involves composing a different organization of perception and conceptualization. Because our native language carries our personal self-representation as well as our "national-cultural epistemology", we naturally cling to it.

There have been a number of attempts to validate this paradigm. A first approach, using the Micromentary Expression test (a measure of empathy based on ability to recognize changes in a woman's expression on a film) did not hold up. A more successful experiment suggested that students became less inhibited and pronounced an unknown foreign language (Thai) better after consuming a small amount of alcohol. In another study, the pronunciation of students who were hypnotizable improved more when hypnotized than the pronunciation of less hypnotizable students (Schumann, Holroyd and Campbell 1978).

Although these studies have not reached the stage where we feel comfortable when we describe personality conditions for second language learning, there is clearly something of importance here. We might speculate for instance about the differential preferences of the introverted and extroverted learner, the former benefiting from conditions of learning that permit quiet introspection and the latter from approaches that encourage immediate public performance. This kind of personality difference supposes the probable weakness of making a generalization such as the claim for the silent period in the work of Krashen, Terrell and Asher. For some learners, a silent period is clearly essential; for others, it is likely to be of little value, and may even lead to lowered motivation. It is also possible that approaches like those of Gattegno, Lozanov and Curran represent attempts to modify conditions in such a way as to overcome the effect of personality matters.

The disparity between teachers' expectations of the language learning task permeates the latter issue. We wish to suggest that any second language learner brings to the language learning situation a set of notions of what is involved in the task; these expectations interact with personality factors and the actual learning situation to determine the strategies that the learner will adopt. For example, the early second language learner (the bilingual who is virtually learning two languages as a first language) quickly learns that the two languages function just like two styles or registers in a single language: Some people expect you to use one language or register, and others expect you to use the other. The later second language learner is likely to consider second language learning similar to the aspect of first language learning that is most salient, usually the learning of vocabulary. The learner who has had a solid dose of formal grammar either in a first or second language will ask similar questions in a new language learning situation. The person to whom a language serves specific social or instrumental purposes will ask how to say the appropriate things. The person who sets very high demands on his or her control of language will 
similarly expect to achieve a high level of control of the new language, and will often be inhibited from trying to learn if there is some danger of being misunderstood or considered less than highly skilled. Methods for relaxation of anxiety, such as those of Gattegno, Lozanov and Curran, or approaches that call on adults to act like uninhibited children, are aimed at this situation.

Condition 10 (graded typical): A learner's expectations of the outcome of language learning interact with learner's personality factors to determine the selection of preferred learning strategies.

We have looked in this paper at evidence from linguistic theory and psycholinguistics for some of the conditions for second language learning that are present in the learner. These factors are all marked by their relative lack of openness to external influence: We do not normally expect to be able to change them. As a result, their direct relevance for language teaching is either in selecting students for special kinds of training or in providing hypotheses for the likelihood of success or failure of various kinds of learning situations. They do, however, illustrate the power and potential of the preference model for deriving a theory of second language learning.

\section{Notes}

1 Jackendoff (1983:12) rejects the possibility of computer modelling as a constraint on a semantic theory because of the difference between present day computers whose processing is serial and the brain, the processing of which is interactive and parallel. But it would seem that Expert Systems (in Artificial Intelligence) are in fact an attempt to develop models with properties very similar if not identical to the preference model.

2 Cook points out that Chomsky $(1980: 230)$ finds the term communicative competence wrong, for there are many purposes of language beyond communication.

3 The notion is worth considering, however, for while we assume that all normal human beings have legs, some have the kind of legs that will help them later become ballet dancers or long distance runners.
4 As Cook (1985) points out, Chomsky argues that even "pure" learning theories of behaviourism assume an innate ability to make associations between stimulus and response.

\section{Bibliography}

BIALYSTOK, Ellen. 1982. On the relationship between knowing and using linguistic forms. $A p$ plied Linguistics 3(3).

CHOMSKY, Noam. 1980. Rules and representations. Oxford: Blackwell.

- - - 1981. Lectures on government and binding. Dordrecht, Holland: Foris Publications.

- - - 1982. Some concepts and consequences of the theory of government and binding. Cambridge, MA: MIT Press.

COHEN, A.D. 1982. Neurolinguistics and second language acquisition. TESOL Quarterly 16(3).

COOK, Vivian J. 1985. Chomsky's universal grammar and second language learning. Applied Linguistics 6(1).

CUMMINS, Jim. 1980. The cross-lingual dimensions of language proficiency: implications for bilingual education and the optimal age issue. TESOL Quarterly 14.

- $\ldots$ 1984a. Wanted: A theoretical framework for relating language proficiency to academic achievement among bilingual students. Rivera, Charlene (ed.) Language proficiency and academic achievement. Clevedon: Multilingual Matters.

DULAY, Heidi \& BURT, Marina. 1974. A new perspective on the creative construction processes in child second language acquisition. Language Learning 24(2).

ERVIN-TRIPP, Susan. 1974. Is second language learning like the first? TESOL Quarterly 8.

FATHMAN, Ann. 1975. The relationship between age and second language productive ability. Language Learning 25(2). 
FELIX, Sascha W. 1981. The effect of formal instruction on second language acquisition. Language Learning 31(1).

GALLOWAY, Linda M. 1981. The convolutions of second language: A theoretical article with a critical review and some new hypotheses towards a neuropsychological model of bilingualism and second language performance. Language Learning 31(2).

GARDNER, R.C. 1979. Social psychological aspects of second language acquisition. Giles, $\mathbf{H}$. \& St Clair, R. (eds.) Language and Social Psychology. Oxford: Blackwell.

- - - 1983. Learning another language: a true social psychological experiment. Journal of Language and Social Psychology 2.

GARDNER, R.C. \& LAMBERT, W.E. 1959. Motivational variables in second language acquisition. Canadian Journal of Psychology 13.

- - - 1972. Attitudes and motivation in second language learning. Rowley, MA: Newbury House.

GENESEE, F. 1976. The role of intelligence in second language learning. Language Learning 26(2).

1982. Experimental neuropsychological research on second language processing. $T E$ SOL Quarterly 16(3).

GUIORA, Alexander Z. 1982. Language, personality and culture: or the Whorfian hypothesis revised. Hines, M. \& Rutherford, W. (eds.) On TESOL'81. Washington, DC: TESOL.

- - - 1983. The dialectic of language acquisition. Language Learning 33(5) special issue.

GUIORA, Alexander Z. \& ACTON, William R. 1979. Personality and language: a restatement. Language Learning 29(1).
HATCH, Evelyn Marcussen. 1983. Psycholinguistics: a second language perspective. Rowley, MA: Newbury House.

JACKENDOFF, Ray. 1983. Semantics and cognition. Cambridge, MA: MIT Press.

KRASHEN, S.D. 1982. Principles and practice in Second Language Acquisition. Oxford: Pergamon Institute of English.

MACNAMARA, John. 1973. The cognitive strategies of language learning. Oller and Richards.

OBLER, Loraine K. 1983. Knowledge in neurolinguistics: the case of bilingualism. Language Learning 33(5) special issue.

OLLER, John W. Jr. 1981. Language as intelligence. Language Learning 31 .

_. - 1984. "g", what is it? Hughes, A. \& Porter, D. (eds.) Current developments in language testing. London: Academic Press.

SCHUMANN, John H. 1975. Affective factors and the problem of age in second language acquisition. Language Learning 25(2).

SCHUMANN, John H. et al. 1978. Improvement of foreign language pronunciation under hypnosis: a preliminary study. Language Learning 28(1).

SPOLSKY, Bernard. (In press a). Towards a theory of second language learning. Studies in second language acquisition.

- - - - (In press b). What does it mean to know how to use a language: an essay on the theoretical basis of language testing. Language Testing.

STERN, H.H. 1983. Fundamental concepts of language teaching. Oxford: Oxford University Press.

SWAIN, Merrill. 1981. Time and timing in bilingual education. Language Learning 31(1). 